\title{
Adjacent Consonants and the Universality of Sonority Sequencing Principle in Dotyali Dialects: Syllable Contact Analysis
}

\author{
Dharm Dev Bhatta \\ Sichuan Normal University, College of Liberal Art, Chengdu China \\ Email: 2784136286@qq.com
}

\begin{abstract}
This paper presents on all the possible adjacent consonant letters in Dotyali, one of the descendant language of Sanskrit, mainly spoken in Shudoor Paschim Nepal [sudvrə-pəssimə] (Far-western) and compares the results of their phonological changes in seven local contemporary speech (dialects): Doteli, Dadeldhuri, Bajhangi, Achhami, Baitadeli, Darchuli and Bajureli. Based on the corpus data from the field survey conducted in between July-September 2017 on a list of 1000 frequently used Dotyali words, this paper comes with a conclusion that even the onset clusters with rising sonority profile (except glides) are broken up by vowel epenthesis or simplify the clusters by deletion. It is revealed that dialects, except from the Achhami and Bajureli, the consonants with different degree of sonority across the syllable boundary tend to be changed due to syllable contact to meet Sonority hierchy, but the sonority distance between two consonants (coda and onset consonants) varies, therefore phonological changes like assimilation, dissimilation, desonorization, contact anaptyxis, contact methasis etc. goes differently. The phonological changes in Bajureli occurs maily due to other separate independent constraints.
\end{abstract}

Keywords: Dotyali Dialects; Sonority Sequencing Principle; Syllable Contact; Survey

\section{A. Introduction}

Dotyali is an umbrella term that embodies all its contemporary 7 dialects, which was the official language of "Doti Kingdom (1238-1790 AD)" [1], [2] in the western part of Nepal (present Shudoor Paschim Province) and its surrounding districts and boarder districts of India, which forms a unique system in phonetics, grammar, vocabulary and written literature different from other Indian languages as Nepali, Hindi, Maithili, Sanskrit etc.. In its past 800 years, the pronunciation of vocabulary has

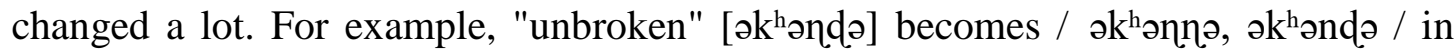
dialects. In this study, we can't determine the exact time of such phonological changes of adjacent consonants across the syllable boundary, we only summarize how the syllable contact repairs wide variety of sonority sequences (i) falling and flat, (ii) rising and narrow on its input form (formal or the written form) in the different contemporary speech ( out put).

Dotyali exhibits moderately complex syllable structure and the most elaborate 
permitted syllable is CGVX ( $\mathrm{X}=$ short vowel/ a consonant, as in "believe" / pət.tjæu.no / -CVC-CGVV.CV), shows that the only permissible sequence at onset is the consonant+glide $(\mathrm{CG} / \mathrm{j}, \mathrm{w} /)$ [3] that follows an 'optimal syllable'. Sonority Sequencing Principle (SSP) predicts that the sonority increases towards the nucleus, then decreases away from the nucleus towards the coda [4 ]. The CGVX structured syllable in Dotyali is restricted in monosyllabic words and word final position [3] that creates the possibility of adjacent consonant sequences across the syllable boundary. Here at least the two basic questions arise: (i) Do all consonants are permissible at coda? What types of consonant sequences are permissible in Dotyali dialects? Do the adjacent consonants (input form) and their sound changes (output form) in Dotyali dialects is induced by syllable contact?

The basic idea about the syllable contact is that languages try to avoid the sequence of rising sonority (bad contact) across the syllable boundary [5], [6], [7]. "Syllable Contact Law" holds that syllable breaks favor decreasing sonority and demands the sonority distence between the coda the following adjacent onset initial be as large as possible[8]. The notion of a sonority distance stratum*DIST+6 stresses that each constraint encompasses with the sonority rise of 6 interval (both kinds of sequences: fricative-glide or stop-rhotic) [4]. The above mentioned phenomena at least for Dotyali dialects are debatable because not all the dialects follow sonority hierarchy across the syllable boundary. Even the dialects that respect syllable contact law do not strictly makes the sonority distance by 6 interval points, as not all the preferred coda consonants are [+sonorant] and preferred onset initials are [-sonorant]. However, syllabification of Dotyali dialects cannot be affected by sonority hierarchy (bad contact) or sonority distance, as consonant clusters are strictly restricted. Regarding input clusters at onset, the epenthesis breaks up all types of onset consonant clusters (CC) and epenthesis site is determined by syllable contact,i.e, the contact epenthesis is peripheral if $\mathrm{C} 1$ is more sonorous than $\mathrm{C} 2(\mathrm{CCV} \rightarrow \mathrm{VC} . \mathrm{CV})$, but epenthesis is internal if $\mathrm{C} 1$ is less sonorous than $\mathrm{C} 2(\mathrm{CCV} \rightarrow \mathrm{CV} . \mathrm{CV})$. For example "Female" Stri (CCCV) is pronounced as /Is.tr.ri/ Is.to.rI/ (i.e [CCCV] input $\rightarrow$ VC.CV.CV(output) [3], where edge epenthesis [I] emerges before sibilant because of the falling or flat sonority between /st/, but internal epenthesis in rising sonority (between/tr/). Here the two different predictions that syllable contact analysis predicts meet here: (i) The inserted vowel before the cluster breaks the cluster but don't interrupt falling/ flat sonority clusters (sequences). (ii) The internal epenthesis breaks up the clusters and the sequences that have bad contact get changed (rising sonority).

Sonority shows the resonance of one sound segment in relation to another [5],[6]. Sonorous sounds are more prominent in amplitude and length than less sonorous sounds. In binary terms, the sonorants [+son] (glides-liquids-nasals) are more sonorous than the obstruent [-son] (fricatives - affricates -stops), However, only this binary grouping is insufficient in Dotyali, as there exists a hierarchy of sonority even within its obstruent. The Sonority Scale (Most sonorous -Least sonorous) of Dotyali consonant can be assumed: [+son] glides $14>$ rhotics $13(\mathrm{r} / \mathrm{r})>$ lateral12 $>$ nasals11 $>$ 
[-son] voiced aspirated affricate10> voiced aspirated stops9>voiced unaspirated fricatives $8>$ voiced unaspirated affricate $7>$ voiced unaspirated stops $6>$ voiceless aspirated affricate $5>$ voiceless aspirated stops $4>$ - voiceless unaspirated fricatives $3>$ voiceless unaspirated affricate2 >voiceless unaspirated stops1 [4].

Dotyali shares most of the consonant letters used in Devanagari writing system, but not all of them phonologically make distinction in its speech which are presented in the table 1. Consonant in brackets are observed as allophones.

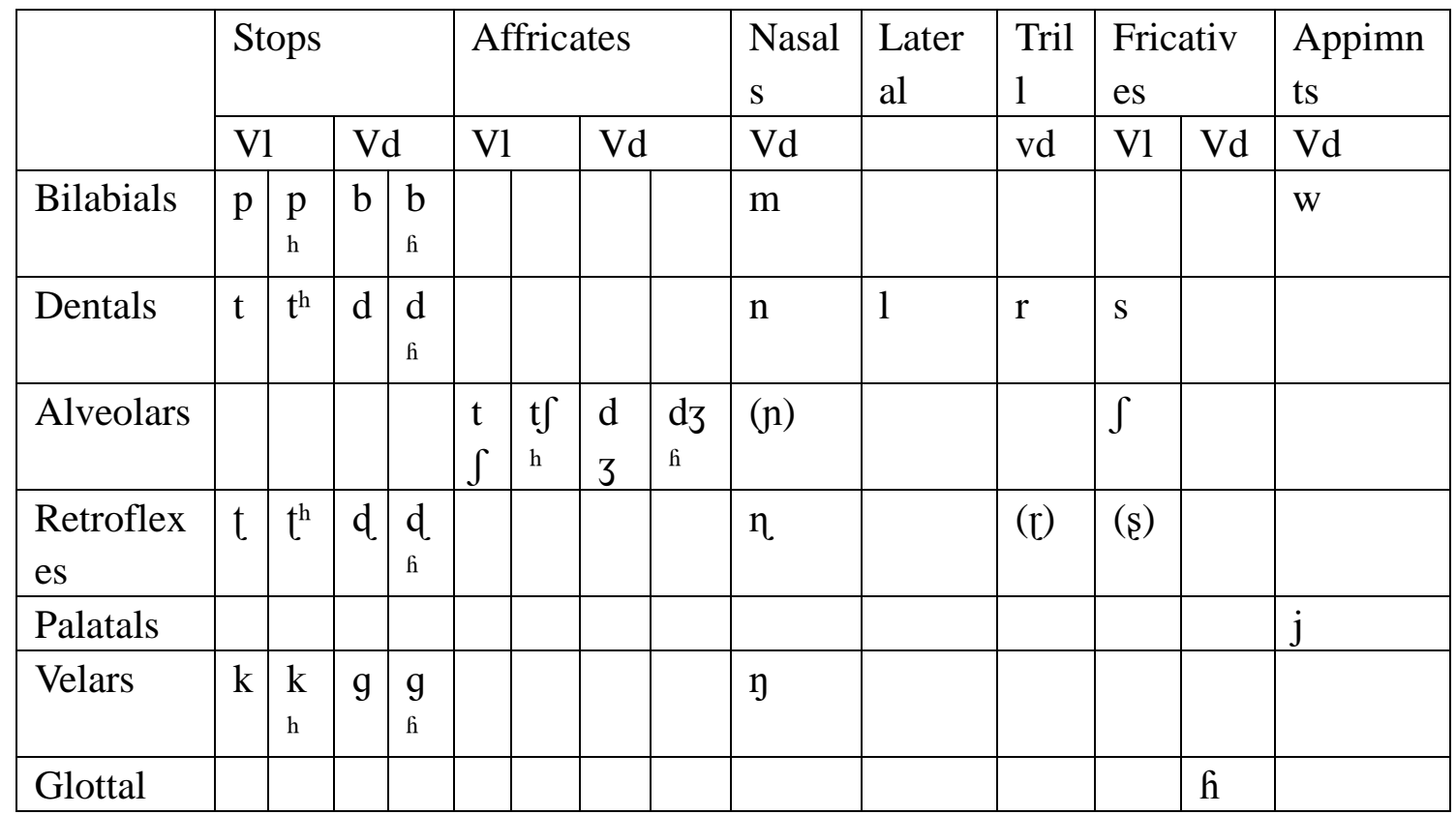

Table 1. Dotyali Consonant Inventory [3]

$[\mathrm{n}]$ is the allophone of $[\mathrm{y}]$ before glide [j] as in "here"[ $\mathrm{nja} / \mathrm{yæ}]$, it gets dentalized [n] in between vowels and at coda; [s] only exhibits in Sanskrit loanwords and usually gets dentalized [s] ,it is often pronounced [kh] followed by other sibilant due to dissimilation. Similarly, separate letter for the retorization of trill $[\mathrm{r}]$ and retroflex stopṣ [r] is common in Old Dotyali writing, which only exists in contemporary speech [r]. Moreover, not all the Dotyali consonant segments have equal distribution in its syllable. The distributional restrictions of Dotyali consonant phoneme is shown in table (2), where the symbols: _ marks phonetic environment, \# matks syllable boundary, \#_ $\mathrm{v}$ marks beginning of a syllable, /v_v/ marks intervocalic position, /v_cv/: at coda (proceeding syllable), and /vc_v/ marks at onset initial (following syllable).

\begin{tabular}{|c|c|c|c|c|}
\hline \multirow{2}{*}{ Phoneme } & $\begin{array}{c}\text { Word } \\
\text { Initial }\end{array}$ & \multicolumn{3}{|c|}{ Word Medial Position } \\
\cline { 2 - 5 } & /\#_V/ & /V_V/ & /V_CV & / VC_V \\
& & & $/$ & / \\
\hline$[\mathrm{n}]$ & - & + & + & + \\
\hline[]$]$ & + & - & - & - \\
\hline
\end{tabular}




\begin{tabular}{|c|c|c|c|c|}
\hline$[\mathrm{j}, \mathrm{w}, \mathrm{h}]$ & + & + & - & - \\
\hline Asprated & + & $\mp$ & $\mp$ & $\mp$ \\
\hline Others & + & + & + & + \\
\hline
\end{tabular}

Table 2. Distributional Restrictions of Dotyali Consonant

Dotyali retroflex nasal $[\eta]$ is restricted at word initial onset position; Palatal sibilant [ $\left.\int\right]$ only makes distinction to dental [s] before glides and long high vowels; Semi-vowel (glides) [j, w] and voiced fricative [ $\mathrm{h}]$ don't make adjacent to any other consonant across the syllable boundary. Aspirated sounds (stops/affricates) in between vowels generally get unaspirated and devoiced [3] and their sequence across syllable boundary varies in dialects, which is either determined by the syllable contact or due to other separate independent constraints, it will be discussed in (3).

\section{B. Methodology}

This paper employed a list of 1000 frequently used Dotyali words "The Basic Vocabulary for Dotyali Dialects Survey" compiled by Bhatta for Ph.d dissertation [3], that includes most of the commonly used words from the book "The History and Spoken Language of That Time"[9] , and "Vocabulary for the Nepalese Language Survey ( LinSuN) " [10 ].

The field survey in 7 dialects: Dhunga-Doti, Babangaun-Dadeldhura, Shaphe-Achham, Martadi-Bajura, Golai-Bajhang, Patan- Baitadi, Gartaula-Darchula, was completed in between July-September 2017 . The seven male native speakers without any academic degree and above 60 years from their respective district, who live within a small particular area and have very little communication with the people of other language comunities were selected for the corpus data. During this survey, Praat and "Feifeng language field survey software" developed by Professor Pan Wuyun and others from Shanghai Normal University was employed and the sampling rate of recording was $44100 \mathrm{HZ}$ and the length of recording (waveform) each word was 5 seconds. Before recording, the speaker were asked to be familiar with the words from our vocabulary list to make sure that he knows each word and can pronounce it accurately in his native tongue. Then, the recording materials were transcribed using International Phonetic Alphabet.

\section{Result and Discussion}

\subsection{Rising sonority and Syllable Contact}

Generally, rising sonority at syllable boundary remains unchanged in Achhami and Bajureli dialect and syllable contact cannot strengthen the sonority of coda or weaken the sonority of adjacent onset initial. Only the obstruent-nasal sequence in verb gets repaired in Achhami. Other some minor changes like devoicing, loss of aspiration and internal epenthesis are not because of syllable contact but due to an independent constraint that aspirated are restricted at coda or onset initial. The bad 
Jadila: Journal of Development and Innovation

contact at syllable boundary gets repaired in other dialects, some examples are given below.

\section{Obstruent-sonorant sequence}

\section{Fricative, affricates, plosives - liquids}

a. All the Obstruent - liquid $\rightarrow$ no change/ Achhami and Bajureli:

- $\quad$ sn, sm, sr, sl (ex. "ladder" lisnช, "calcify" briəsmə, "real "əslı, "a kind of tree "k $\mathrm{k}^{\mathrm{h}} \mathrm{sr}$ )

- dzr, pr $\rightarrow$ no change, (ex. "thunder" bədzrə, "well grow" səprənひ )

- $\quad$ dil $\rightarrow$ dl, (ex. " grow" bədila $\rightarrow$ bədla)

Though the voiced consonant at coda gets devoiced but it is not due to syllable contact as it could not repair sonority hierarchy. In addition, the devoicing increases rising sonority interval, which goes the opposition of syllable contact law.

b. Other dialects:

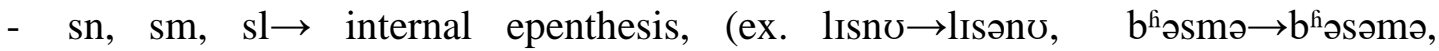
əsli $\rightarrow$ วsəli)

- $\mathrm{sr} \rightarrow \mathrm{rs}$, ( contact metathesis ), (ex. $\mathrm{k}^{\mathrm{h}}$ əsru $\rightarrow \mathrm{k}^{\mathrm{h}}$ ərs $)$

- dzr , pr $\rightarrow$ Contact epenthesis, (ex. bədzrə $\rightarrow$ bədzorə/ bədzoro, səprənu $\rightarrow$ səpərnno/ səpəddu)

- $\quad \mathrm{d}^{\mathrm{d}} \mathrm{l} \rightarrow \mathrm{rl}$ (retorization), (ex. bəd ${ }^{\mathrm{f}} \mathrm{la} \rightarrow$ bərəlo, bərəla, bərla)

Contact epenthesis (anyptysix), contact metathesis, retorization of stops (sonorization) changes rising sonority into falling sonority. Coda ([ $\left.\mathrm{d}^{\mathrm{f}}\right]$ ) losses aspiration and got retorized not because it is restricted but for strengthening coda.

\section{Plosives/ affricates -nasal}

a. All plosives/ affricates - nasal $\rightarrow$ no change / Bajureli

b. All plosives/ affricates- nasal $\rightarrow$ regressively assimilated / Baitadeli and Darchuli.

- Voiceless plosives /affricates - nasal ([obs-son]) $\rightarrow$ ([obs-obs]), (ex. "pluck" tIpn $\rightarrow$ tIppə/tıppo, "put" rak $\left.^{\mathrm{h}} \mathrm{n} \rightarrow \mathrm{rak}^{\mathrm{h}} \mathrm{k}^{\mathrm{h}} \mathrm{\gamma} / \mathrm{rak}^{\mathrm{h}} \mathrm{k}^{\mathrm{h}} \mathrm{\partial}\right)$

- Voiced aspirated plosives /affricates - $\mathrm{n}([\mathrm{obs}-\mathrm{son}]) \rightarrow$ ([obs-obs]), (ex. "mix"gabin $\mho \rightarrow$ gabb $/$ gabbə)

The voiced aspirated coda first loss aspiration, then the onset initial gets assimilated. However the regressive assimilation weakens the sonority of onset initial and changes the rising sonority sequences into null sonority sequences.

c. Other dialects:

- Voiceless plosives /affricates - $\mathrm{n}([\mathrm{obs}-\mathrm{son}]) \rightarrow([\mathrm{obs}-\mathrm{obs}])$, desonorizes the onset initial, (ex. tIpn $\rightarrow$ tIpdə/ tIpd,$\left.\quad \operatorname{rak}^{\mathrm{h}} \mathrm{n} \mho \rightarrow \mathrm{rak}^{\mathrm{h}} \mathrm{d} \delta / \mathrm{rak}^{\mathrm{h}} \mathrm{d} ə\right)$

- Voiced aspirated plosives /affricates $-\mathrm{n}([$ obs-son] $) \rightarrow($ [obs-obs] $)$ desonorizes the onset initial, (ex.gab ${ }^{\mathrm{h}} \mathrm{n} \mho \rightarrow$ gabd $/$ gabdə),

First the onset gets desonorized (become obstruent), than coda obstruent gets devoiced (weakened) in order to repair the sonority hierachy between the coda and the onset. 
Exceptions:

- $\quad \mathrm{t} \int, \mathrm{t}, \mathrm{d} 3, \mathrm{t}^{\mathrm{h}}-\mathrm{n}([\mathrm{obs}-\mathrm{son}]) \rightarrow([\mathrm{obs}-\mathrm{obs}])$ regressively assimilated / all dialects

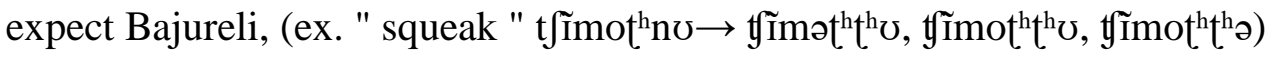

- $p^{\mathrm{h}} \mathrm{n} \rightarrow$ internal epenthesis (ə) / all dialects expect Bajureli (ex. "own"

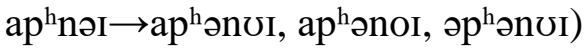

\section{Nasal-liquids}

a. ml, $\mathrm{yl} \rightarrow$ no change / Achhami and Bajureli , (ex. "lemon" əmla /Imla, "basket" naylo )

b. $\mathrm{ml}, \mathrm{yl} \rightarrow$ internal epenthesis $(\mathrm{\partial} / \mathrm{I}) /$ Other dialects, (ex. əmla $\rightarrow$ əməla/ımıla, nạlo $\rightarrow$ nayəlo)

\section{Obstruent- Obstruent}

\section{Voiceless-voiced}

a. $\mathrm{kd} \rightarrow$ no change/ Achhami and Bajureli , (ex. "can do" səkdo)

b. $\mathrm{kd} \rightarrow \mathrm{gd}$ (progressively assimilated ) / Other dialects, (ex. səkdo $\rightarrow$ səgdo )

Coda strengthening through progressive assimilation, changing rising sonority sequences into equal sonority sequences.

\section{Unaspirated-aspirated}

a. Unaspirated-aspirated $\rightarrow$ no change or coda drop off / Achhami and Bajureli, (ex. "slate" pəttherə $\rightarrow$ pəttherə, pat ${ }^{\text {horə) }}$

b. Unaspirated-aspirated $\rightarrow$ no change / Baitadeli and Darchuli

Regarding the sequence of unaspirated and their aspirated counterpart, the above mentioned dialects respect the rising sonority with just a single sonority interval.

Unaspirated-aspirated $\rightarrow$ progressively assimilated/ Other dialects, (ex. pətt ${ }^{\mathrm{h}} \mathrm{er} \boldsymbol{\rightarrow}$ pathth ${ }^{\text {th }}$ (r)

Only in Doteli, Dadeldhuri and Bajhangi dialect strictly coda gets weakened to repair bad contact sequences.

Exception:

- $\quad \mathrm{dd}^{\mathrm{h}} \rightarrow \mathrm{dd} / \mathrm{d}^{\mathrm{h}} \mathrm{d}^{\mathrm{h}}$ ( get assimilated in all dialects ) ( ex. "Buddha" bəodd $\partial \rightarrow$ bəoddə, "worm " gədd $\mathrm{e} \rightarrow \operatorname{gad}^{\mathrm{h}} \mathrm{d}^{\mathrm{h}} \mathrm{e}$ ). Both process (regressive/progressive) changes rising sonority into equal (null) sonority.

\section{Plosive-affricate}

a. pt $\int$, bdz $\rightarrow$ no change / Achhami and Bajureli, (ex. "lock" kəpt $\left.\int a\right)$

c. Other dialects:

- $p t \int \rightarrow$ bdz (ex. kəpt $\left.\int a \rightarrow k ə b d z a\right)$

- $\quad$ bdz $\rightarrow$ no change ( ex. kəbdza $\rightarrow$ kəbdza/ kabdza)

\section{Plosive- fricative}


Generally, plosive- fricative sequences are rarely found in Dotyali and its dialects. Only /ks/ sequence very frequent in Sanskrit loanwords that gets repaired in two ways: (i) Coda drops off, (ii) Assimilation.

a. $\mathrm{k}_{\mathrm{s}} \rightarrow \mathrm{t}^{\mathrm{h}} \mathrm{t} \mathrm{f}^{\mathrm{h}} \mathrm{g} / \mathrm{t} \int$ / Doteli, Dadeldhuri, Bajhangi, Baitadeli, (ex. "monster" rakşəsə $\rightarrow$ rat $\int^{\text {ht }} f^{\text {he }}$ esə/ ragəsə, "witness"sakși $\rightarrow$ sãtfi )

First the affrication of sibilant weakens the onset, then only the coda gets strengthened through progressive assimilation and repairs the bad contact. Another way is coda/ initial drop.

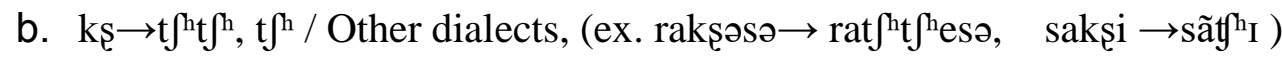

\subsection{Falling sonority and Syllable Contact}

The changing of adjacent consonant across the syllable boundary mainly occurs not for maintaining sonority distance. Except from Bajureli, the less the sonority distance, the more adjacent consonant tend to repair sonority.

\section{Sonorant-sonorant}

\section{Retoric- Liquids}

a. $\quad r l \rightarrow$ no change /Achhami and Bajureli, (ex. "may die" mərla)

b. $\mathrm{rl} \rightarrow$ internal epenthesis (ə) / other dialects, (ex., mərla $\rightarrow$ mərəla/ merəlo )

Though the sequence faiths the falling sonority across the syllable boundary but sonority interval is less, therefore internal epenthesis breaks the sequence in other dialects except Achhami and Bajureli.

\section{Retoric- nasal}

a. $\quad r n, r m \rightarrow$ no change/ Bajureli, (ex.,"graze" t $\left.\int ə r n u \rightarrow t \int ə r n \mho\right)$

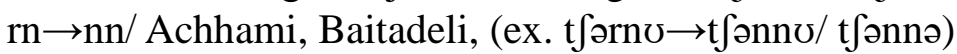

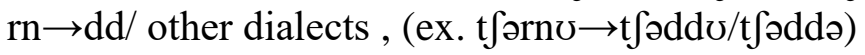

b. $\mathrm{rm} \rightarrow$ internal epenthesis (ə) /all dialects except Bajureli, (ex. "shyness" sərmə $\rightarrow$ sərəmə)

c. $\quad$ n $\rightarrow$ rn / Achhami, Baitadeli and Bajureli, (ex. " River (name)" kərnali $\rightarrow$ kərnalı) (only appear in noun)

$\mathrm{rn} \rightarrow$ no change / other dialects

Coda [r] gets reversely assimilated in Achhami and Baitadeli and reduces sonority interval. In other dialects the onset nasal first gets desonorized, then only the coda gets progressively assimilated, the process goes like: $\mathrm{t}$ ərn $\mho \rightarrow \mathrm{t} \int \partial r d \mho \rightarrow \mathrm{t} \int \partial \mathrm{dd} \sigma$, $-\mathrm{rn} \rightarrow \mathrm{rd} \rightarrow \mathrm{dd}$.

\section{Lateral- nasal}

$\ln \rightarrow 11$ / except Bajureli (ex. "fall" d

Regressive assimilation in dialects except Bajureli ( $\ln \rightarrow 11)$ changes of falling sonority sequence into equal ( null) sonority sequence.

\section{Sonorant-obstruent}

\section{Rethoric (Trill ) - stops/ affricates / fricative}

Rhetoric and obstruents makes the greatest sonority distance in between coda and onset initial, they generally do not change in dialects. But, Bajhangi and Darchuli 
dialect tend to maintain less sonority distance between coda and onset, therefore africates in onset get strengthen by a single sonority interval. Except Bajureli, Bajhangi and Darchuli, other dialects weaken the onset and maintain higher sonority distance.

\section{Bajani and Darchuli}

a. $\quad \mathrm{rt} f \rightarrow \mathrm{rd} 3$ (voicing) / in nouns, ( ex. "spend" $\mathrm{k}^{\mathrm{h}} \mathrm{rrt}^{\mathrm{h}}{ }^{\mathrm{h}} \mathrm{a} \rightarrow \mathrm{k}^{\mathrm{h}}$ ərdzə)

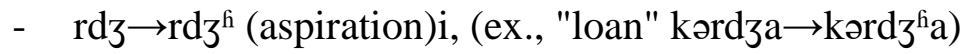

b. $\quad \mathrm{rt}^{\mathrm{h}} \rightarrow$ no change / nouns

- $\quad \operatorname{rtf}^{\mathrm{h}}\left(\mathrm{rt} \int^{\mathrm{h}}\right.$ ) $\rightarrow$ a syllable insertion ([ən]) / in verbs (except Achhami and Bajureli)

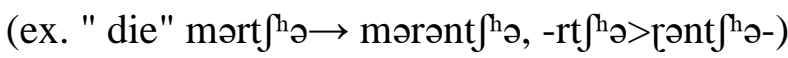

c. r-voiced aspirated $\rightarrow$ lose aspiration / except Bajhangi and Darchuli, (ex."dead body" mərd $\rightarrow$ morda)

\section{Lateral- stops/ affricates / fricative}

Generally, the adjacent of lateral and other stops and affricates remains unchanged in all dialects,few exception:

a. $\quad$ ld $\rightarrow \mathrm{dl} /$ Bajureli ( ex. " Turmeric" həldo $\rightarrow$ hədlo

Change of falling sonority into rising sonority through contact metathesis.

b. $\quad l k \rightarrow l g$ (voicing) / Bajhangi (ex. " pecify " pəlka $\rightarrow$ pəlga)

c. ld $\rightarrow$ no change / Achhami and Bajureli

$\mathrm{ld} \rightarrow \mathrm{ld} / \mathrm{dd} /$ Bajhangi, (ex. "pit" k ${ }^{\mathrm{h}}$ aldo $\rightarrow \mathrm{k}^{\mathrm{h}}$ aldo $/ \mathrm{k}^{\mathrm{h}}$ addo)

$\mathrm{ld} \rightarrow \mathrm{lt}$ (devoicing) / Other dialects (ex. $\mathrm{k}^{\mathrm{h}} \mathrm{ald} \mathrm{o} \rightarrow \mathrm{k}^{\mathrm{h}}$ alto)

d. $\quad$ lt $\int \rightarrow$ ldz (voicing ) /except Achhami and the Bajureli (ex. "lock" talt $\int a \rightarrow$ taldza)

$.1 \mathrm{t} f \rightarrow \operatorname{ld} 3^{\mathrm{h}}$ (aspirated) in Bajhangi and Baitadeli (ex. taldza $\rightarrow$ tald $3^{\mathrm{h}} \mathrm{a}$ )

$1 d 3^{\mathrm{f}} \rightarrow \operatorname{ld} 3$ (loss aspiration) /except Bajhangi and Baitadeli (ex. taldza $\rightarrow$ tald $3^{\mathrm{f}} \mathrm{a}$ )

\section{Nasal- stops/ affricates / fricative}

a. nd, $\mathrm{nt}^{\mathrm{h}} \rightarrow \mathrm{nd}$, $\mathrm{nt}^{\mathrm{h}}$ (dissimilated) / Achhami and Bajureli (ex. "unbroken "

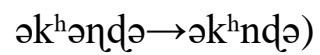

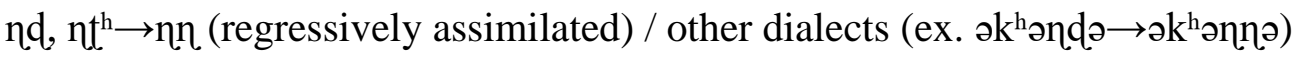

Inorder to achieve the less sonority distence in falling sequences, the coda or the onset gets weakened through contact dissimilation and assimilation

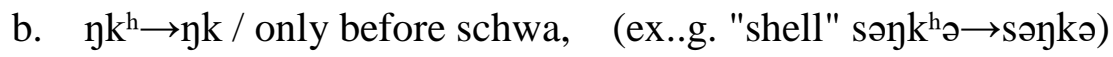

$\mathrm{yg} \rightarrow \mathrm{yy} / \mathrm{y}$ (coda drops off) / Doteli, Dadeldhuri and Achhami, (ex." aspicious" məygələ, məyyəla, maylə)

c. $\quad \mathrm{m}, \mathrm{n}$ - aspirated plosives/affricates $\left(\mathrm{p}^{\mathrm{h}}, \mathrm{t} \mathrm{f}^{\mathrm{h}}, \mathrm{k}^{\mathrm{h}}, \mathrm{b}^{\mathrm{h}}, \mathrm{d}^{\mathrm{h}}\right) \rightarrow$ lose aspiration ( before

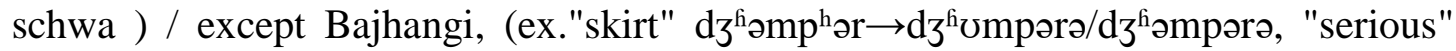
gəmb $b^{\text {firə }} \rightarrow$ gəmbirə, "father-in-law" səmd $\mathrm{d}^{\mathrm{i}} \rightarrow$ somdI/ səmdi)

$\mathrm{m}$ - unaspirated stops and fricatives $\left(\mathrm{t}, \mathrm{t}, \mathrm{t} \int \mathrm{d} 3, \mathrm{k}, \mathrm{d}, \mathrm{p}\right) \rightarrow$ no change/ Doteli, Dadeldhuri and Achhami

$\mathrm{mt}, \mathrm{mt}, \mathrm{mt} \int \rightarrow$ coda drop off (vowel gets nasalized) / except Doteli, Dadeldhuri and Achhami

(ex., "pine" simto $\rightarrow$ sĩuto, "tweezers" t $\int \mathrm{Im} t a \rightarrow t$ Ĩvta, "Spoon" t $\left.\int ə m t \int a \rightarrow t \int \tilde{I} v t \int a\right)$ 
d. $\mathrm{ms} \rightarrow \mathrm{ms} / \mathrm{ns} / \mathrm{ns}$ ( no regularity (sonority preserved) , (ex.: "break"

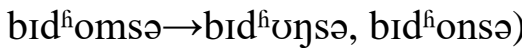

$\mathrm{ns} \rightarrow \mathrm{t} \int^{\mathrm{h}}$ (affication)/ Achhami and Bajureli , (ex. "human" mənsə $\rightarrow \operatorname{mant} \int^{\mathrm{h}}$, mant $\left.\int \mathrm{e}\right)$

$$
\text { ns } \rightarrow \text { no change / other dialects }
$$

\section{Obstruent-obstruent ( falling sonority) Fricative- plosive}

Achhami and Bajureli:

a. $\quad$ st, sb $\rightarrow$ no change (ex. "same/similar" dzəstəI $\rightarrow$ dzəstor/dzəstəI)

b. $\mathrm{st}^{\mathrm{t}} \rightarrow \mathrm{st} \quad$ (ex. "Surname" əwəst $\mathrm{t}^{\mathrm{h}} \rightarrow$ ost $/$ /2bəst $)$

Baitadeli and Darchuli:

a. st,sd, $\rightarrow$ ss (regressively assimilated ) (ex. dzəstəI $\rightarrow$ dzəssəI, "Sitting" bəsda $\rightarrow$ bəssa )

b. $\mathrm{s}^{\mathrm{t}} \rightarrow \mathrm{t}^{\mathrm{h}} \mathrm{t}^{\mathrm{h}}$ in (ex. "Surname" əwəst $\left.\mathrm{s}^{\mathrm{h}} \rightarrow \mathrm{ot}^{\mathrm{h}} \mathrm{t}^{\mathrm{h}} \mathrm{I}\right)$

Other dialects:

a. $\quad$ st $\rightarrow$ ss (regressively assimilated ) (ex. dzəstəI $\rightarrow$ dzəssəI )

b. sd, st $\mathrm{t}^{\mathrm{h}} \rightarrow \mathrm{t}^{\mathrm{h}} \mathrm{t}^{\mathrm{h}}\left(\mathrm{ex}\right.$. "Sitting" bəsda $\rightarrow$ bət $t^{\mathrm{h}} \mathrm{t}^{\mathrm{h}} \mathrm{a}$, "Surname" əwəst $\left.\mathrm{t}^{\mathrm{h}} \mathrm{i} \rightarrow \mathrm{ot}^{\mathrm{h}} \mathrm{t}^{\mathrm{h}} \mathrm{I}\right)$

\section{Plosive-plosive}

a. $\mathrm{d}^{\mathrm{h}} \mathrm{t}, \mathrm{d}^{\mathrm{h}} \mathrm{d} \rightarrow \mathrm{rt} / \mathrm{rt}, \mathrm{dd} / \mathrm{dd}$ ( respectively) / except Bajureli

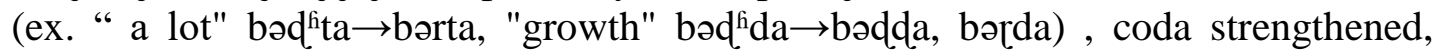
onset strengthened through dissimilation and assimilation

b. $d^{\mathrm{h} t} / \mathrm{d}^{\mathrm{h}} \mathrm{d} \rightarrow \mathrm{dt}$, dd (coda weakened and ) / Bajureli (ex. bəd $\mathrm{d}^{\mathrm{h}} \mathrm{ta} \rightarrow$ bədta, bəd $\mathrm{d}^{\mathrm{h}} \mathrm{da} \rightarrow$ bədda)

\section{3 Equal (null) sonority and syllable contact}

\section{Nasals}

a. $\quad \mathrm{mn} \rightarrow$ no change/ Bajureli (ex. "move" $\mathrm{g}^{\mathrm{f}} \mathrm{vmn}$ ) $\mathrm{mn} \rightarrow \mathrm{mm}$ ( assimilated) /Baitadeli and Darchuli (ex. $\mathrm{g}^{\mathrm{h}} \mathrm{\sigma mn} \mho \rightarrow \mathrm{g}^{\mathrm{h}} \mathrm{\sigma mm}$, $g^{\text {fiommo) }}$

$\mathrm{mn} \rightarrow \mathrm{md}$ ( dissimilated) / other dialects, (ex. $\mathrm{g}^{\mathrm{h}} \mathrm{m} \mathrm{mn} \cup \rightarrow \mathrm{g}^{\mathrm{h}} \mathrm{O} \mathrm{md}$ )

b. $\mathrm{nm} \rightarrow$ internal epenthesis/ Bajangi, Achhami, and Darchuli, (ex."birth" dзənmə $\rightarrow$ dzənəmə) $\mathrm{nm} \rightarrow$ no change/ other dialects

\section{Plosives}

a. pt, pk $\rightarrow$ no change/ all dialects, ( ex. "week" səptafiə $\rightarrow$ səptafia/ səpta)

b. pt $\rightarrow$ coda drop off / Doteli, Dadeldhuri, Baitadeli, and Darchuli, (ex. "pour (move)" $g^{\mathrm{h}}$ opto $\rightarrow g^{\mathrm{h}}$ ovto)

c. $\mathrm{kt} \rightarrow \mathrm{tk}$ ( transposition) / exxcept Bajureli, ( ex." flesh" t fokto $\rightarrow \mathrm{t}$ Jotko)

From the above mention examples and roles of syllable contact in different dialects, it is cleared that Bajureli not only has preserved most of the ill-formed sequences (obstruent-sonorant, nasal-liquids, plosive-affricate, voiceless-voiced, unaspirated-aspirated) in which the latter one (onset initial) is higher in sonority than 
the former one (coda), even the well-formed adjacent consonant gets metathesized and strengthen the sonority of onset initial. Moreover, Achhami and Bajureli prefer the onset initial be more sonorous than preceding coda and the greater the sonority distance, the better. If the sonority distance is less, the coda tends to drop off or weakened by de-sonorizing, devoicing, diaspiration etc.. Except Achhami and Bajureli dialects, the syllable contact over ill-formed adjacent consonants and sonority distance in a word treats differently. Baitadeli and Darchuli prefer the smaller the distance, the better. But, Doteli, Dadeldhuri and Bajhangi favor the greater the fall of sonority in between the coda and onset initial, the better. The less the sonority fall be repaired by internal epenthesis or simply by other phonological process. That is just opposite in Bajureli and Achhami. In other words, less-more sonorous adjacent consonant are very frequent in Bajureli and Achhami, more- less sonorous adjacent consonant are frequent in Doteli, Dadeldhuri and Bajhangi.

\section{Conclusion}

This comparative study shows that though syllable contact constraints works out mostly but not fully, Syllable contact in OT can be marginal in some dialects of the same language. In case of Dotyali dialects, though most of the dialects are faithful to Syllable contact law, still the syllable contact can not be the characteristic of Dotyali, because even the dialect that prefer syllable and syllable slope also respect the two consonant with the same sonority across the syllable boundary and the sonority rise/fall greater than 1 sonority interval over a syllable boundary are also acceptable, which is not just limited within obstruent-obstruent, voicelss-voiced, unaspiratedaspirated sequences and vice versa. The Syllable Contact in Dotyali dialects play an important role to structure the dialectal phonology but it doesn't exactly require codas to be as sonorant as possible, and onsets to be as non-sonorant as possible.

This study is the summary of all the possible adjacent consonants and their sound change due to syllabus contact that makes the dialects phonoogically unique. As these dialects are spoken in a small area and have on influence eachother, the syllable contact rules alone may not be sufficient for the shape of dialectal phonology. However,we believe that our first step findings will support further research on Dotyaly and its dialectal phonology.

\section{Appendix}

Vocabulary

Rising Sonority Sequences

\begin{tabular}{|l|l|l|l|l|l|l|l|l|}
\hline $\begin{array}{l}\text { Gloss with IPA } \\
\text { (Formal lg) }\end{array}$ & Doteli & $\begin{array}{l}\text { Dade } \\
\text { ldhur } \\
\text { i }\end{array}$ & $\begin{array}{l}\text { Bajha } \\
\text { ngi }\end{array}$ & $\begin{array}{l}\text { Achh } \\
\text { ami }\end{array}$ & $\begin{array}{l}\text { Baitad } \\
\text { eli }\end{array}$ & $\begin{array}{l}\text { Darc } \\
\text { huli }\end{array}$ & $\begin{array}{l}\text { Bajur } \\
\text { reli }\end{array}$ \\
\hline
\end{tabular}


Jadila: Journal of Development and Innovation

E-ISSN: 2723-6900

in Language and Literature Education

P-ISSN: 2745-9578

Publisher: Yayasan Karinosseff Muda Indonesia

Volume 1 Number 3, 2021

Page: 254-270

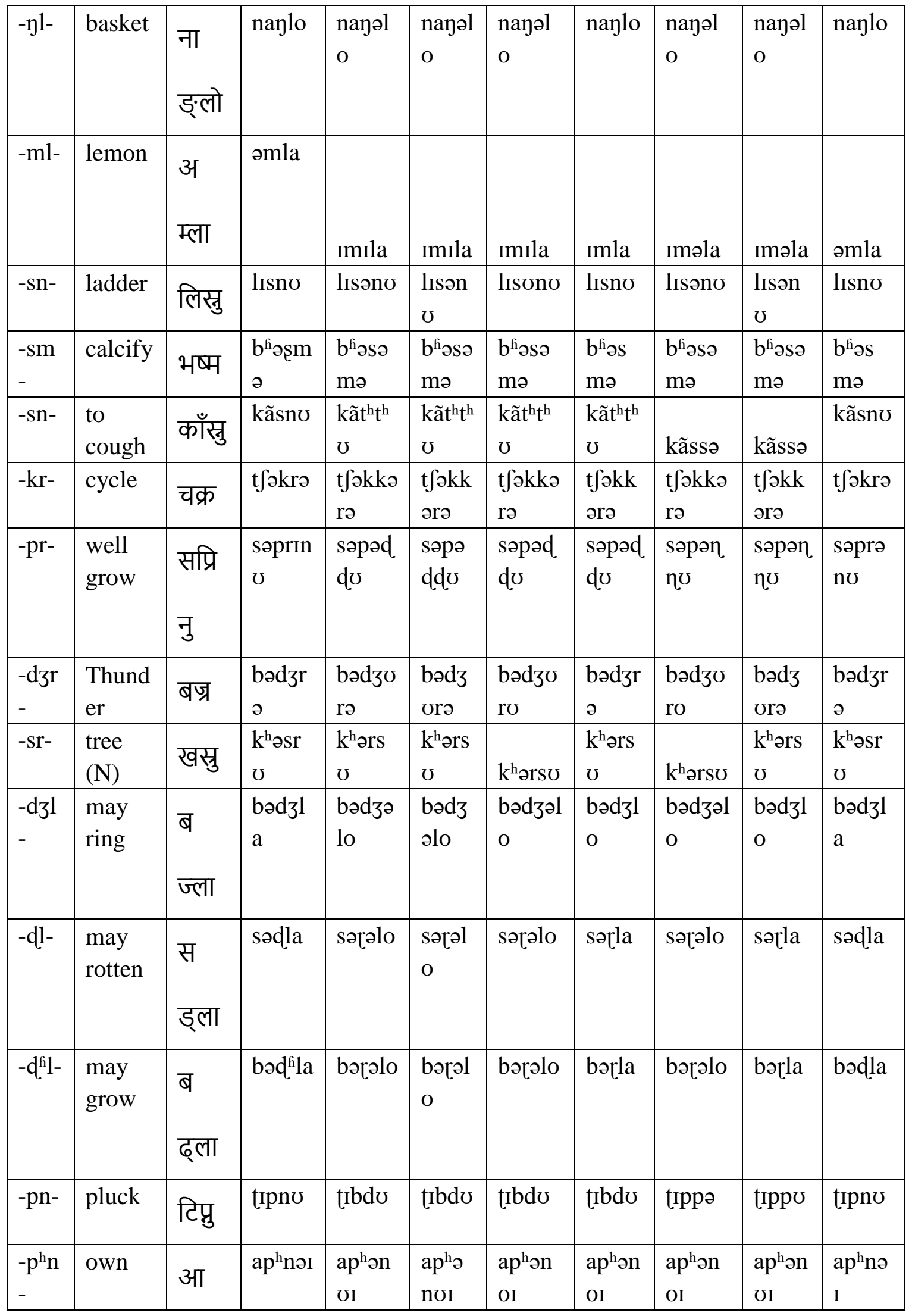


Jadila: Journal of Development and Innovation

E-ISSN: 2723-6900

in Language and Literature Education

P-ISSN: 2745-9578

Publisher: Yayasan Karinosseff Muda Indonesia

Volume 1 Number 3, 2021

Page: 254-270

\begin{tabular}{|c|c|c|c|c|c|c|c|c|c|c|}
\hline & & फ्नै & & & & & & & & \\
\hline$-t^{\mathrm{h}} \mathrm{n}-$ & squeak & चिँमो & $\begin{array}{l}\text { t } \int \tilde{I} \text { imot } \\
\text { hnv }\end{array}$ & $\begin{array}{l}\text { tٓİmət } \\
{ }^{\mathrm{h}} \mathrm{t}_{\mathrm{U}}\end{array}$ & $\begin{array}{l}\text { t timə } \\
\mathrm{t}^{\mathrm{h}} \mathrm{t}^{\mathrm{h}} \mathrm{C}\end{array}$ & $\begin{array}{l}\text { tyimot }{ }^{\mathrm{h}} \\
\text { th}^{\mathrm{h}_{U}}\end{array}$ & $\begin{array}{l}\text { trimət } \\
{ }^{\mathrm{h}} \mathrm{t}^{\mathrm{h}}{ }\end{array}$ & $\begin{array}{l}\text { tyimət }{ }^{\text {h }} \\
\text { thə }\end{array}$ & $\begin{array}{l}\text { tĩmot } \\
{ }^{\mathrm{h}} \mathrm{t}^{\mathrm{h}} \mathrm{U}\end{array}$ & 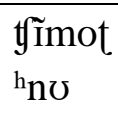 \\
\hline$-k^{\mathrm{h}} \mathrm{n}$ & keep & राख्नु & $\begin{array}{l}\operatorname{rak}^{\mathrm{h}} \mathrm{n} \\
\mho\end{array}$ & $\begin{array}{l}\operatorname{rak}^{\mathrm{h}} \mathrm{d} \\
\mho\end{array}$ & $\begin{array}{l}\operatorname{rak}^{\mathrm{h}} \mathrm{d} \\
\mho\end{array}$ & $\operatorname{rak}^{\mathrm{h}} \mathrm{d} v$ & $\begin{array}{l}\operatorname{rak}^{\mathrm{h}} \mathrm{d} \\
\mho\end{array}$ & $\begin{array}{l}\operatorname{rak}^{\mathrm{h}} \mathrm{k}^{\mathrm{h}} \\
\partial\end{array}$ & $\begin{array}{l}\operatorname{rak}^{\mathrm{h}} \mathrm{k} \\
\mathrm{h}_{U}\end{array}$ & $\begin{array}{l}\operatorname{rak}^{\mathrm{h}} \mathrm{n} \\
\mho\end{array}$ \\
\hline$-b^{f} n$ & merge & गाभ्नु & $\begin{array}{l}\mathrm{gab}^{\mathrm{f}} \mathrm{n} \\
\mho\end{array}$ & gabdv & $\begin{array}{l}\text { gabd } \\
\mho\end{array}$ & gabdv & $\begin{array}{l}\text { gabd } \\
\mho\end{array}$ & gabbə & $\begin{array}{l}\text { gabb } \\
\mho\end{array}$ & $\begin{array}{l}\text { gabn } \\
\mho\end{array}$ \\
\hline$-d^{-d^{h} n}$ & grow & बढ़नु & $\begin{array}{l}\text { bəd }^{\mathrm{f}} \mathrm{n} \\
\mho\end{array}$ & $\begin{array}{l}\text { baddu } \\
\text { / } \\
\text { bəddu }\end{array}$ & $\begin{array}{l}\text { badd } \\
\mho / \\
\text { bədd } \\
\mho\end{array}$ & baddu & $\begin{array}{l}\text { bodd } \\
\mho\end{array}$ & baddo & $\begin{array}{l}\text { badd } \\
\mho\end{array}$ & $\begin{array}{l}\text { bədn } \\
\mho\end{array}$ \\
\hline$-\mathrm{kS}_{\mathrm{Q}}-$ & $\begin{array}{l}\text { monst } \\
\text { er }\end{array}$ & $\begin{array}{l}\text { राक्ष } \\
\text { स }\end{array}$ & $\begin{array}{l}\text { rakşs } \\
\partial\end{array}$ & $\begin{array}{l}\text { rat } \int^{h} \text { t } \\
\text { hesə/ } \\
\text { ragəs } \\
\text { ə }\end{array}$ & $\begin{array}{l}\text { rat } \int^{h t} \\
\int^{h} \text { esə } \\
/ \text { ragə } \\
\text { sə }\end{array}$ & $\begin{array}{l}\text { rat } \int^{h} \int^{h} \\
\text { esə/ } \\
\text { ragəsə }\end{array}$ & $\begin{array}{l}\operatorname{rat}^{\text {ht }} \\
\int^{\text {hes }}\end{array}$ & $\begin{array}{l}\text { rat } \int^{h} \int^{h} \\
\text { esə/ra } \\
\text { gəsə }\end{array}$ & $\begin{array}{l}\text { rat } \int^{\text {ht }} \\
\int^{\text {hese }}\end{array}$ & $\begin{array}{l}\text { rat } \mathrm{h}^{\mathrm{t}} \int \\
\text { hesə }\end{array}$ \\
\hline & $\begin{array}{l}\text { witnes } \\
\mathrm{S}\end{array}$ & साँक्षी & saksi & sãtfI & sãtf I & $\operatorname{sat}^{h_{I}}$ & sãtf I & sãtf I & $\operatorname{satf}^{h_{I}}$ & $\operatorname{sat}^{\mathrm{h}_{\mathrm{h}}}$ \\
\hline \multicolumn{11}{|c|}{ Falling Sonority Sequences } \\
\hline -rk- & $\begin{array}{l}\text { pastur } \\
\mathrm{e}\end{array}$ & खर्क & $\begin{array}{l}\mathrm{k}^{\mathrm{h}} \text { ərk } \\
\partial\end{array}$ & $\begin{array}{l}\mathrm{k}^{\mathrm{h}} \text { ərk } \\
\partial\end{array}$ & $\begin{array}{l}\mathrm{k}^{\mathrm{h}} \text { ərk } \\
\partial\end{array}$ & $\mathrm{k}^{\mathrm{h} ə r k ə}$ & $\begin{array}{l}\mathrm{k}^{\mathrm{h}} \text { ərk } \\
\text { ə }\end{array}$ & $\mathrm{k}^{\mathrm{h}}$ ərkə & $\begin{array}{l}\mathrm{k}^{\mathrm{h}} \partial \mathrm{rk} \\
\partial\end{array}$ & $\begin{array}{l}\mathrm{k}^{\mathrm{h}} \text { ərk } \\
\partial\end{array}$ \\
\hline \multirow[t]{2}{*}{$-\mathrm{rt} \int^{\mathrm{h}}$} & dies & मई & $\begin{array}{l}\text { mərt } \int^{h} \\
\partial\end{array}$ & $\begin{array}{l}\text { mərən } \\
\mathrm{t} \int^{\mathrm{h}} \partial\end{array}$ & $\begin{array}{l}\text { mərə } \\
\mathrm{nt} \int^{\mathrm{h} \partial}\end{array}$ & $\begin{array}{l}\text { mərən } \\
\mathrm{t} \int^{\mathrm{h}} \partial\end{array}$ & $\begin{array}{l}\text { mərə } \\
\mathrm{nt} \int^{\mathrm{h}} \mathrm{\partial}\end{array}$ & $\begin{array}{l}\text { mərt } \int^{h} \\
\partial\end{array}$ & $\begin{array}{l}\text { mərə } \\
\text { nt } \int^{\text {hy }}\end{array}$ & $\begin{array}{l}\text { mərt } \int \\
\mathrm{h}_{\partial}\end{array}$ \\
\hline & faint & मुर्छा & $\begin{array}{l}\text { mort } \\
\mathrm{h}_{\mathrm{a}}\end{array}$ & $\begin{array}{l}\text { mort } \\
\mathrm{h}_{\mathrm{a}}\end{array}$ & $\begin{array}{l}\text { mort } \\
\int^{h_{h}} \mathrm{a}\end{array}$ & $\begin{array}{l}\text { mort }{ }^{h} \\
\text { a }\end{array}$ & $\begin{array}{l}\text { mort } \int \\
\mathrm{h}_{\mathrm{a}}\end{array}$ & $\begin{array}{l}\text { mort }{ }^{h} \\
\text { a }\end{array}$ & $\begin{array}{l}\text { mort } \int \\
\mathrm{h}_{\mathrm{a}}\end{array}$ & $\begin{array}{l}\text { mort } \int \\
\mathrm{h}_{\mathrm{a}}\end{array}$ \\
\hline $\begin{array}{l}-r b^{\mathrm{fi}} \\
-\end{array}$ & $\begin{array}{l}\text { concei } \\
\text { ve }\end{array}$ & गर्भ & $\begin{array}{l}\text { gərb }^{\mathrm{h}} \\
\partial\end{array}$ & gərbə & $\begin{array}{l}\text { gorb } \\
\partial\end{array}$ & gərb $^{\text {fi }}$ & gərbə & gərbə & $\begin{array}{l}\text { gərb }^{\mathrm{f}} \\
\partial\end{array}$ & gərbə \\
\hline -rd3 & loan & कर्जा & $\begin{array}{l}\text { kərd3 } \\
\text { a }\end{array}$ & $\begin{array}{l}\text { kərd3 } \\
\text { ə }\end{array}$ & $\begin{array}{l}\text { kərd } \\
\text { 3ə }\end{array}$ & $\begin{array}{l}\text { kərdz } 3^{\mathrm{h}} \\
\mathrm{a}\end{array}$ & $\begin{array}{l}\text { kərd3 } \\
\text { a }\end{array}$ & $\begin{array}{l}\text { kərd3 } \\
\text { a }\end{array}$ & $\begin{array}{l}\text { kərd3 } \\
\text { fia }\end{array}$ & $\begin{array}{l}\text { kərd3 } \\
\text { a }\end{array}$ \\
\hline $\begin{array}{l}-\mathrm{rd3} \\
\mathrm{fi}_{-}\end{array}$ & $\begin{array}{l}\text { wither } \\
\text { ed }\end{array}$ & मुर्झा & $\begin{array}{l}\text { mord } \\
3^{\text {ha }} a\end{array}$ & $\begin{array}{l}\text { mord } \\
\text { 3a/ } \\
\text { modz } \\
\text { a }\end{array}$ & $\begin{array}{l}\text { mord } \\
\text { 3a/m } \\
\text { vdza }\end{array}$ & $\begin{array}{l}\text { mordz } \\
\text { fa }\end{array}$ & $\begin{array}{l}\text { mord } \\
\text { 3a/ } \\
\text { mod3 } \\
\text { a }\end{array}$ & $\begin{array}{l}\text { mordz } \\
\text { a/ } \\
\text { modz } \\
\text { a }\end{array}$ & $\begin{array}{l}\text { mord } \\
3^{\text {fi }} a\end{array}$ & $\begin{array}{l}\text { mord } \\
3^{a} / \\
\bmod _{3} \\
a\end{array}$ \\
\hline -rs- & $\begin{array}{l}\text { hot/be } \\
\text { at }\end{array}$ & बर्सा & bərsa & bərsa & bərsa & bərsa & bərsa & bərsa & bərsa & bərsa \\
\hline$-\mathrm{rm}-$ & $\begin{array}{l}\text { modes } \\
\text { ty }\end{array}$ & सर्म & sərmə & $\begin{array}{l}\text { sərəm } \\
\text { ə }\end{array}$ & $\begin{array}{l}\text { sərə } \\
\text { mə }\end{array}$ & sərmə & $\begin{array}{l}\text { sərə } \\
\text { mə }\end{array}$ & $\begin{array}{l}\text { sərəm } \\
\text { ə }\end{array}$ & $\begin{array}{l}\text { sərə } \\
\text { mə }\end{array}$ & sərmə \\
\hline
\end{tabular}


Jadila: Journal of Development and Innovation

E-ISSN: 2723-6900

in Language and Literature Education

P-ISSN: 2745-9578

Publisher: Yayasan Karinosseff Muda Indonesia

Volume 1 Number 3, 2021

Page: 254-270

\begin{tabular}{|c|c|c|c|c|c|c|c|c|c|c|}
\hline -rn- & graze & चर्नु & t fərno & $\begin{array}{l}\text { t〕ədd } \\
\mho\end{array}$ & $\begin{array}{l}\text { t } \partial \mathrm{dd} \\
\mho\end{array}$ & $\mathrm{t} \int \partial \mathrm{ddd} v$ & $\begin{array}{l}\text { t〕ənn } \\
\mho\end{array}$ & t $\int \partial n n ə$ & $\begin{array}{l}\text { t } \partial \mathrm{dd} \\
\mho\end{array}$ & $\begin{array}{l}\text { t } \partial r n \\
\mho\end{array}$ \\
\hline \multirow[t]{2}{*}{-rn- } & River & कर्णा & $\begin{array}{l}\text { kərnal } \\
\text { i }\end{array}$ & $\begin{array}{l}\text { kərnal } \\
\text { I }\end{array}$ & $\begin{array}{l}\text { kərn } \\
\text { alı }\end{array}$ & $\begin{array}{l}\text { kərnal } \\
\text { I }\end{array}$ & $\begin{array}{l}\text { kərna } \\
\text { li }\end{array}$ & $\begin{array}{l}\text { kərnal } \\
\text { I }\end{array}$ & $\begin{array}{l}\text { kərna } \\
\text { li }\end{array}$ & $\begin{array}{l}\text { kərna } \\
\text { li }\end{array}$ \\
\hline & $\begin{array}{l}\text { may } \\
\text { die }\end{array}$ & मर्ला & mərla & $\begin{array}{l}\text { meral } \\
\text { o }\end{array}$ & $\begin{array}{l}\text { merə } \\
\text { lo }\end{array}$ & $\begin{array}{l}\text { merəl } \\
\text { o }\end{array}$ & mərla & $\begin{array}{l}\text { mərəl } \\
\mathrm{a}\end{array}$ & $\begin{array}{l}\text { mərəl } \\
\text { a }\end{array}$ & mərla \\
\hline -lt- & $\begin{array}{l}\text { rudun } \\
\text { dant }\end{array}$ & फा & $\mathrm{p}^{\mathrm{h}}$ altu & $\mathrm{p}^{\mathrm{h}}$ altu & $\begin{array}{l}p^{\text {halt }} \\
\mho\end{array}$ & $\mathrm{p}^{\mathrm{h}}$ altu & $\begin{array}{l}p^{\text {halt }} \\
\mho\end{array}$ & $\mathrm{p}^{\mathrm{h}}$ alto & $\begin{array}{l}\mathrm{p}^{\mathrm{h}} \mathrm{alt} \\
\mho\end{array}$ & $\mathrm{p}^{\mathrm{h}}$ alt $\mathrm{s}$ \\
\hline -ld- & $\begin{array}{l}\text { turmer } \\
\text { ic }\end{array}$ & हल्दो & həldo & həldo & $\begin{array}{l}\text { həld } \\
\text { o }\end{array}$ & foldo & həldo & həldo & həldo & fədlo \\
\hline -lt- & upside & उल्टो & vlto & $\begin{array}{l}\text { vlto、 } \\
\text { vltı }\end{array}$ & $\begin{array}{l}\text { vlto、 } \\
\text { vltı }\end{array}$ & vltI & vltI & vlto & vlto & vlto \\
\hline -ld- & pit & $\begin{array}{l}\text { खा } \\
\text { ल्डो }\end{array}$ & $\begin{array}{l}\mathrm{k}^{\mathrm{h}} \mathrm{ald} \\
\mathrm{o}\end{array}$ & $\mathrm{k}^{\mathrm{h}}$ alto & $\begin{array}{l}\mathrm{k}^{\mathrm{h}} \text { alt } \\
\mathrm{o}\end{array}$ & $\begin{array}{l}\mathrm{k}^{\mathrm{h}} \text { aldo } \\
/ \mathrm{k}^{\mathrm{h}} \text { add } \\
\mathrm{o}\end{array}$ & $\begin{array}{l}\mathrm{k}^{\mathrm{h}} \text { ald } \\
\mathrm{o}\end{array}$ & $\mathrm{k}^{\mathrm{h}}$ alto & $\begin{array}{l}\mathrm{k}^{\mathrm{h}} \text { alt } \\
\mathrm{o} \text {, }\end{array}$ & $\begin{array}{l}\mathrm{k}^{\mathrm{h}} \text { ald } \\
\mathrm{o}\end{array}$ \\
\hline$-1 \mathrm{k}-$ & pecify & $\begin{array}{l}\text { प } \\
\text { ल्का }\end{array}$ & pəlka & pəlka & pəlka & pəlga & pəlka & pəlka & pəlka & pəlka \\
\hline$-1 \mathrm{t} \int-$ & $\begin{array}{l}\text { padloc } \\
\mathrm{k}\end{array}$ & $\begin{array}{l}\text { ता } \\
\text { ल्चा }\end{array}$ & talt $\int a$ & taldza & $\begin{array}{l}\text { tald3 } \\
\text { a }\end{array}$ & $\begin{array}{l}\text { taldz }^{\mathrm{f}} \\
\mathrm{a}\end{array}$ & talt $\int a$ & taldza & $\begin{array}{l}\text { tald3 } \\
\text { a }\end{array}$ & talt $\int \mathrm{a}$ \\
\hline $\begin{array}{l}-l d 3 \\
f_{-}\end{array}$ & $\begin{array}{l}\text { entang } \\
\text { le }\end{array}$ & $\begin{array}{l}\text { अ } \\
\text { ल्झा } \\
\text { उनु }\end{array}$ & $\begin{array}{l}\text { old } 3^{\mathrm{h}} \mathrm{a} \\
\text { onv }\end{array}$ & oldza & əldza & əld $z^{\mathrm{h}} \mathrm{a}$ & əldza & əldza & əldza & oldza \\
\hline$-1 \mathrm{tg}^{\mathrm{h}_{-}}$ & lazy & $\begin{array}{l}\text { अ } \\
\text { ल्छि }\end{array}$ & $\operatorname{\partial lt}{ }^{h} I_{I}$ & əlsI & əlsI & əlsI & $\partial \operatorname{llg}^{h_{I}}$ & əlsI & əlsI & $\operatorname{eltgh}^{h}$ \\
\hline$-\ln$ & fall & ढल्नु & $\begin{array}{l}d^{\text {fi } \partial \ln } \\
\mho\end{array}$ & $\mathrm{d}^{\mathrm{f}}$ əllu & $\begin{array}{l}\text { dfill } \\
\mho\end{array}$ & $\mathrm{d}^{\mathrm{f}} \partial 1 \mathrm{ll} v$ & $\begin{array}{l}\text { dfill } \\
\mho\end{array}$ & $\mathrm{d}^{\mathrm{f}}$ əllə & $\begin{array}{l}d^{f} \text { əll } \\
\mho\end{array}$ & $\begin{array}{l}\mathrm{d}^{\mathrm{f}} \partial \ln \\
\mho\end{array}$ \\
\hline
\end{tabular}


Jadila: Journal of Development and Innovation

E-ISSN: 2723-6900

in Language and Literature Education

P-ISSN: 2745-9578

Publisher: Yayasan Karinosseff Muda Indonesia

Volume 1 Number 3, 2021

Page: 254-270

\begin{tabular}{|c|c|c|c|c|c|c|c|c|c|c|}
\hline -nd- & $\begin{array}{l}\text { unbro } \\
\text { ken }\end{array}$ & $\begin{array}{l}\text { अख } \\
\text { ण्ड }\end{array}$ & $\begin{array}{l}\partial \mathrm{k}^{\mathrm{h}} \partial \eta \\
\mathrm{d} \partial\end{array}$ & $\begin{array}{l}\partial \mathrm{k}^{\mathrm{h}} \partial \eta \\
\eta \partial\end{array}$ & 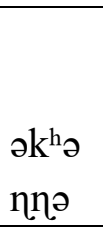 & $\begin{array}{l}\partial \mathrm{k}^{\mathrm{h}} \partial \eta \\
\eta \partial\end{array}$ & $\begin{array}{l}\partial \mathrm{k}^{\mathrm{h}} \partial \mathrm{n} \\
\mathrm{d} \partial\end{array}$ & $\begin{array}{l}\partial \mathrm{k}^{\mathrm{h}} \eta \eta \\
\partial\end{array}$ & $\begin{array}{l}\partial \mathrm{k}^{\mathrm{h}} \eta \eta \\
\partial\end{array}$ & $\begin{array}{l}\partial \mathrm{k}^{\mathrm{h}} \mathrm{nd} \\
\partial\end{array}$ \\
\hline -nt- & bell & घण्टा & $g^{\text {fi } ə \eta t a ~}$ & $g^{\mathrm{f}} \partial \eta t a$ & $\begin{array}{l}g^{\mathrm{f}} \partial \eta t \mathrm{t} \\
\mathrm{a}\end{array}$ & $\mathrm{g}^{\mathrm{f}} \partial \eta t \mathrm{a}$ & $\begin{array}{l}\mathrm{g}^{\mathrm{h}} \partial \mathrm{n} t \\
\mathrm{a}\end{array}$ & $g^{\text {fionta }}$ & $\begin{array}{l}g^{\text {fi } \partial n t} \\
\mathrm{a}\end{array}$ & $\begin{array}{l}\mathrm{g}^{\mathrm{f}} \partial \mathrm{t} t \\
\mathrm{a}\end{array}$ \\
\hline \multirow[t]{2}{*}{$-\eta \mathrm{k}^{\mathrm{h}}$} & fan & $\begin{array}{l}\text { प } \\
\text { ड्खा }\end{array}$ & $\begin{array}{l}\text { pəクk }{ }^{h} \\
\text { a }\end{array}$ & $\begin{array}{l}\text { pəクk }{ }^{h} \\
\mathrm{a}\end{array}$ & $\begin{array}{l}\text { pəyk } \\
\mathrm{h}_{\mathrm{a}}\end{array}$ & $\begin{array}{l}\text { pəyk } \mathrm{k}^{\mathrm{h}} \\
\mathrm{a}\end{array}$ & $\begin{array}{l}\text { pəyk } \mathrm{k}^{\mathrm{h}} \\
\mathrm{a}\end{array}$ & $\begin{array}{l}\text { pəク }^{\mathrm{h}} \\
\mathrm{a}\end{array}$ & $\begin{array}{l}\text { pəクk }^{\mathrm{h}} \\
\mathrm{a}\end{array}$ & $\begin{array}{l}\text { pəク } \mathrm{k}^{\mathrm{h}} \\
\mathrm{a}\end{array}$ \\
\hline & $\begin{array}{l}\text { seashe } \\
\text { ll }\end{array}$ & शंख & $\begin{array}{l}\text { səクk } \mathrm{k}^{\mathrm{h}} \\
\partial\end{array}$ & səłkə & $\begin{array}{l}\text { səクk } \\
\partial\end{array}$ & səłkə & səクkə & səłkə & səykə & səクkə \\
\hline$-n g-$ & $\begin{array}{l}\text { auspic } \\
\text { ious }\end{array}$ & $\begin{array}{l}\text { मंड़ } \\
\text { ल }\end{array}$ & $\begin{array}{l}\text { məyg } \\
\text { ələ }\end{array}$ & $\begin{array}{l}\text { məyy } \\
\text { ələ }\end{array}$ & $\begin{array}{l}\text { məy } \\
\text { yələ }\end{array}$ & maylo & $\begin{array}{l}\text { məyy } \\
\text { ələ }\end{array}$ & maylo & $\begin{array}{l}\text { məyə } \\
\text { lə }\end{array}$ & $\begin{array}{l}\text { məџə } \\
\text { lə }\end{array}$ \\
\hline -mt- & $\begin{array}{l}\text { pinefr } \\
\text { uit }\end{array}$ & $\begin{array}{l}\text { सि } \\
\text { म्तो }\end{array}$ & SImto & Simto & $\begin{array}{l}\text { simt } \\
\mathrm{o}\end{array}$ & sĩoto & SImto & SĨoto & sĩuto & Simto \\
\hline -mt- & $\begin{array}{l}\text { tweeze } \\
\text { rs }\end{array}$ & $\begin{array}{l}\text { चि } \\
\text { म्टा }\end{array}$ & $\mathrm{t} \int \mathrm{Im} t \mathrm{a}$ & $\mathrm{t} \int \mathrm{Imta}$ & $\begin{array}{l}\mathrm{t} \int \mathrm{Imt} \\
\mathrm{a}\end{array}$ & $\begin{array}{l}\text { t } \int \mathrm{Imt} / \\
\mathrm{t} \int \mathrm{I} U t \mathrm{a}\end{array}$ & $\begin{array}{l}\mathrm{t} \text { Imt } \\
\mathrm{a}\end{array}$ & $\begin{array}{l}\mathrm{t} \int \mathrm{Im} t a \\
/ \\
\mathrm{t} \int \tilde{\mathrm{I}} \mathrm{ta}\end{array}$ & $\begin{array}{l}\mathrm{t} \int \mathrm{Imt} \\
\mathrm{a} / \\
\mathrm{t} \int \mathrm{I} \sigma \mathrm{ta}\end{array}$ & $\begin{array}{l}\mathrm{t} \int \mathrm{Im} t a \\
/ \\
\mathrm{t} \int \mathrm{I} u t a\end{array}$ \\
\hline$-m$ & spoon & चम्चा & $\begin{array}{l}\mathrm{t} \int \partial \mathrm{mt} \int \\
\mathrm{a}\end{array}$ & $\begin{array}{l}\mathrm{t} \int \mathrm{Imt} \int \\
\mathrm{a}\end{array}$ & $\begin{array}{l}\mathrm{t} \int \mathrm{Imt} \\
\int \mathrm{a}\end{array}$ & $\begin{array}{l}t \int \operatorname{Imt} \int \\
a \\
t \int \tilde{I} u t \int a\end{array}$ & $\begin{array}{l}\mathrm{t} \int \mathrm{Imt} \int \\
\mathrm{a}\end{array}$ & 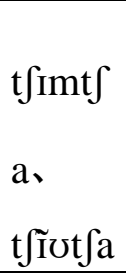 & 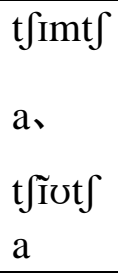 & $\begin{array}{l}\text { tfimt } \\
\text { a 、 } \\
\text { tfĩot } \int \\
\text { a }\end{array}$ \\
\hline $\begin{array}{l}-m p \\
h_{-}\end{array}$ & gawn & $\begin{array}{l}\text { झुम्फ } \\
\text { र }\end{array}$ & $\begin{array}{l}\mathrm{d}^{\mathrm{f}} \mathrm{U} \\
\mathrm{mp} \mathrm{p}^{\mathrm{h}} \partial \mathrm{r} \\
\partial\end{array}$ & $\begin{array}{l}\mathrm{d} 3^{\mathrm{f}} \mathrm{U} \\
\text { mpərə }\end{array}$ & $\begin{array}{l}\mathrm{d} 3^{\mathrm{h}} \circlearrowright \\
\mathrm{mp} \partial \mathrm{r} \\
\partial\end{array}$ & $\begin{array}{l}\mathrm{d} 3^{\text {hi } \partial \mathrm{m}} \\
\mathrm{p}^{\mathrm{h}} \partial \mathrm{r} \partial\end{array}$ & $\begin{array}{l}\mathrm{d} 3^{\mathrm{f}_{\mho}} \\
\text { mpor } \\
\text { ə }\end{array}$ & $\begin{array}{l}\mathrm{d} 3^{\mathrm{f}} \partial \mathrm{m} \\
\text { pərə }\end{array}$ & $\begin{array}{l}\mathrm{d} 3^{\mathrm{h}} \mathrm{U} \\
\mathrm{mp} \\
\partial\end{array}$ & $\begin{array}{l}\mathrm{d} 3^{\mathrm{h}} \mathrm{U} \\
\mathrm{mp} \partial \mathrm{r} \\
\partial\end{array}$ \\
\hline $\begin{array}{l}-m b \\
\mathrm{~h}_{-}\end{array}$ & $\begin{array}{l}\text { seriou } \\
\text { S }\end{array}$ & $\begin{array}{l}\text { गम्भी } \\
\text { र }\end{array}$ & $\begin{array}{l}\text { gəmb } \\
\text { firə }\end{array}$ & $\begin{array}{l}\text { gəmbI } \\
\text { rə }\end{array}$ & $\begin{array}{l}\text { gəm } \\
\text { birə }\end{array}$ & $\begin{array}{l}\text { gəmb }^{\text {fi }} \\
\text { Irə }\end{array}$ & $\begin{array}{l}\text { gəmb } \\
\text { Irə }\end{array}$ & $\begin{array}{l}\text { gəmbI } \\
\text { rə }\end{array}$ & $\begin{array}{l}\text { gəmb } \\
\text { Irə }\end{array}$ & $\begin{array}{l}\text { gəmb } \\
\text { Irə }\end{array}$ \\
\hline $\begin{array}{l}-m d \\
3^{\mathrm{h}}-\end{array}$ & $\begin{array}{l}\text { explai } \\
\mathrm{n}\end{array}$ & $\begin{array}{l}\text { स } \\
\text { म्झा }\end{array}$ & $\begin{array}{l}\text { somd } \\
3^{\text {hav }}\end{array}$ & $\begin{array}{l}\text { səmd } \\
\text { 3a }\end{array}$ & $\begin{array}{l}\text { səmd } \\
\text { 3a }\end{array}$ & $\begin{array}{l}\text { somd3 } \\
\text { fia }\end{array}$ & $\begin{array}{l}\text { səmd } \\
\text { za }\end{array}$ & $\begin{array}{l}\text { səmd3 } \\
\text { a }\end{array}$ & $\begin{array}{l}\text { səmd } \\
\text { 3a }\end{array}$ & $\begin{array}{l}\text { səmd } \\
\text { 3a }\end{array}$ \\
\hline
\end{tabular}


Jadila: Journal of Development and Innovation

E-ISSN: 2723-6900

in Language and Literature Education

P-ISSN: 2745-9578

Publisher: Yayasan Karinosseff Muda Indonesia

Volume 1 Number 3, 2021

Page: 254-270

\begin{tabular}{|c|c|c|c|c|c|c|c|c|c|c|}
\hline & & उ & & & & & & & & \\
\hline $\begin{array}{l}-m d \\
f_{-}\end{array}$ & $\begin{array}{l}\text { father- } \\
\text { in-law }\end{array}$ & सम्धि & $\begin{array}{l}\text { səmd }^{\mathrm{f}} \\
\mathrm{i}\end{array}$ & somdi & $\begin{array}{l}\text { som } \\
\text { di }\end{array}$ & $\begin{array}{l}\text { səmd }^{\mathrm{f}} \\
\mathrm{I}\end{array}$ & $\begin{array}{l}\text { somd } \\
\text { I }\end{array}$ & səmdI & $\begin{array}{l}\text { sumd } \\
\text { I }\end{array}$ & $\begin{array}{l}\text { somd } \\
\text { I }\end{array}$ \\
\hline $\begin{array}{l}-n t f^{h} \\
-\end{array}$ & people & मान्छे & $\begin{array}{l}\text { mant } \int \\
\mathrm{e}\end{array}$ & $\begin{array}{l}\text { məns } \\
\text { ə }\end{array}$ & $\begin{array}{l}\text { məns } \\
\partial\end{array}$ & mansə & $\begin{array}{l}\text { mant } \\
\int^{\mathrm{h}} \mathrm{\partial}\end{array}$ & mansə & $\begin{array}{l}\text { mant } \\
\int^{\text {ho }}\end{array}$ & $\begin{array}{l}\text { mant } \int \\
\mathrm{e}\end{array}$ \\
\hline $\begin{array}{l}-\mathrm{ms} \\
-\end{array}$ & $\begin{array}{l}\text { demoli } \\
\text { tion }\end{array}$ & $\begin{array}{l}\text { विध्वं } \\
\text { स }\end{array}$ & $\begin{array}{l}\text { bId }^{\mathrm{f}} \mathrm{O} \\
\mathrm{ms} ə\end{array}$ & $\begin{array}{l}\text { bId }^{\mathrm{f}} \circlearrowright \\
\text { ysə }\end{array}$ & $\begin{array}{l}\text { bid }^{\mathrm{f}} \mathrm{U} \\
\text { ysə }\end{array}$ & $\begin{array}{l}\text { bid }^{\mathrm{f}} \text { on } \\
\text { sə }\end{array}$ & $\begin{array}{l}\text { bidf }^{\mathrm{f}} \\
\text { ysə }\end{array}$ & $\begin{array}{l}\text { bid }^{\mathrm{f}} \text { on } \\
\text { sə }\end{array}$ & $\begin{array}{l}\text { bid }^{\mathrm{i}} \mathrm{O} \\
\text { nsə }\end{array}$ & $\begin{array}{l}\text { bid }^{\mathrm{f}} \mathrm{O} \\
\text { nsə }\end{array}$ \\
\hline -st- & similar & जस्तै & $\begin{array}{l}\text { dzəstə } \\
\text { I }\end{array}$ & $\begin{array}{l}\text { dzəSs } \\
\text { əI }\end{array}$ & $\begin{array}{l}\text { dzəss } \\
\text { əI }\end{array}$ & $\begin{array}{l}\text { dzəssə } \\
\text { I }\end{array}$ & $\begin{array}{l}\text { dzəst } \\
\text { OI }\end{array}$ & $\begin{array}{l}\text { dzəssə } \\
\text { I }\end{array}$ & $\begin{array}{l}\text { dzəss } \\
\text { əI }\end{array}$ & $\begin{array}{l}\text { dzəst } \\
\text { əI }\end{array}$ \\
\hline -sd- & Sitting & $\begin{array}{l}\text { ब } \\
\text { ढ्ला }\end{array}$ & bəsda & $\begin{array}{l}\text { bət } t^{h} t^{h} \\
\text { a }\end{array}$ & $\begin{array}{l}\mathrm{b} \mathrm{t}^{\mathrm{h}} \mathrm{t}^{\mathrm{h}} \\
\mathrm{a}\end{array}$ & bət $^{\mathrm{h}} \mathrm{t}^{\mathrm{h}} \mathrm{a}$ & bəsda & bəssa & bəssa & bəsda \\
\hline$-\mathrm{st}^{\mathrm{h}_{-}}$ & $\begin{array}{l}\text { Surna } \\
\text { me }\end{array}$ & $\begin{array}{l}\text { अव } \\
\text { स्थी }\end{array}$ & $\begin{array}{l}\text { əwəst } \\
\mathrm{hi}_{\mathrm{i}}\end{array}$ & ot $^{\mathrm{h}} \mathrm{t}^{\mathrm{h}} \mathrm{I}$ & $\begin{array}{l}\mathrm{ot}^{\mathrm{h}} \mathrm{t}^{\mathrm{h}} \mathrm{I} \\
\end{array}$ & ot $^{\mathrm{h}} \mathrm{t}^{\mathrm{h}} \mathrm{I}$ & ostI & ot $^{\mathrm{h}} \mathrm{t}^{\mathrm{h}} \mathrm{I}$ & ot $^{\mathrm{h}} \mathrm{t}^{\mathrm{h}} \mathbf{I}$ & ostI \\
\hline$-\mathrm{t} \int \mathrm{k}-$ & grab & $\begin{array}{l}\text { प } \\
\text { च्का }\end{array}$ & pət $\int \mathrm{ka}$ & $\begin{array}{l}\text { pətfka } \\
\text { / } \\
\text { pətka }\end{array}$ & $\begin{array}{l}\text { pətfk } \\
\text { a/ } \\
\text { pətka }\end{array}$ & $\begin{array}{l}\text { pətfka } \\
\text { / } \\
\text { pətka }\end{array}$ & $\begin{array}{l}\text { pətJk } \\
\text { a }\end{array}$ & pətfka & $\begin{array}{l}\text { pət } \int k \\
\text { a/ } \\
\text { pətka }\end{array}$ & $\begin{array}{l}\text { potfk } \\
\text { a }\end{array}$ \\
\hline$-\mathrm{d}^{\mathrm{fit}}-$ & extra & ब & bədif $^{\text {ta }}$ & bərta & bərta & bərta & bərta & bərta & bərta & bədta \\
\hline$-d^{\mathrm{f}} \mathrm{d}$ & $\begin{array}{l}\text { growi } \\
\text { ng }\end{array}$ & ब & $\begin{array}{l}\text { bədifd }^{\text {d }} \\
\text { a }\end{array}$ & bədda & $\begin{array}{l}\text { bodd } \\
\text { a }\end{array}$ & bədda & bərda & bərda & $\begin{array}{l}\text { bədd } \\
\text { a }\end{array}$ & bədda \\
\hline -mn & roam & घुम्नु & $\begin{array}{l}g^{\mathrm{f}} \delta \mathrm{m} \\
\text { nJ }\end{array}$ & $\begin{array}{l}\mathrm{g}^{\mathrm{h}} \mathrm{m} \\
\mathrm{d} v\end{array}$ & $\begin{array}{l}\mathrm{g}^{\mathrm{f}} \mathrm{m} \\
\mathrm{d} \mho\end{array}$ & $\begin{array}{l}g^{\text {fir }} \delta m d \\
\mho\end{array}$ & $\begin{array}{l}\mathrm{g}^{\mathrm{f}} \mathrm{m} \\
\mathrm{d} v\end{array}$ & $\begin{array}{l}\mathrm{g}^{\mathrm{h}} \mathrm{\sigma m} \\
\mathrm{m} ə\end{array}$ & $\begin{array}{l}g^{\mathrm{f}} \delta \mathrm{m} \\
\mathrm{m} \mho\end{array}$ & $\begin{array}{l}\mathrm{g}^{\mathrm{f}} \delta \mathrm{m} \\
\mathrm{n} \sigma\end{array}$ \\
\hline \multicolumn{11}{|c|}{ Equal Sonority Sequences } \\
\hline$-n$ & birth & जन्म & $\begin{array}{l}\text { dzən } \\
\text { mə }\end{array}$ & $\begin{array}{l}\text { dzən } \\
\text { mə }\end{array}$ & $\begin{array}{l}\text { dzən } \\
\text { mə }\end{array}$ & $\begin{array}{l}\text { dzənə } \\
\text { mə }\end{array}$ & $\begin{array}{l}\text { dzən } \\
\text { əmə }\end{array}$ & $\begin{array}{l}\text { dzən } \\
\text { mə }\end{array}$ & $\begin{array}{l}\text { dzən } \\
\text { əmə }\end{array}$ & $\begin{array}{l}\text { dzən } \\
\text { mə }\end{array}$ \\
\hline -pt- & $\begin{array}{l}\text { week-1 } \\
\text { ong }\end{array}$ & $\begin{array}{l}\text { सप्ता } \\
\text { ह }\end{array}$ & $\begin{array}{l}\text { səpta } \\
\text { hə }\end{array}$ & səpta: & $\begin{array}{l}\text { səpta } \\
:\end{array}$ & $\begin{array}{l}\text { səptah } \\
\text { a }\end{array}$ & $\begin{array}{l}\text { səpta } \\
\text { ha }\end{array}$ & səpta: & $\begin{array}{l}\text { səpta } \\
:\end{array}$ & səpta: \\
\hline
\end{tabular}


Jadila: Journal of Development and Innovation

E-ISSN: 2723-6900

in Language and Literature Education

P-ISSN: 2745-9578

Publisher: Yayasan Karinosseff Muda Indonesia

Volume 1 Number 3, 2021

Page: $254-270$

\begin{tabular}{|c|c|c|c|c|c|c|c|c|c|c|}
\hline -tk- & lad & जा & $\begin{array}{l}\text { dzatk } \\
\partial\end{array}$ & $\begin{array}{l}\text { dzatk } \\
\partial\end{array}$ & $\begin{array}{l}\text { dzatk } \\
\partial\end{array}$ & $\begin{array}{l}\text { dzatək } \\
\partial\end{array}$ & $\begin{array}{l}\text { dzatə } \\
\text { kə }\end{array}$ & dzatkə & $\begin{array}{l}\text { dzatə } \\
\text { kə }\end{array}$ & $\begin{array}{l}\text { dzatk } \\
\partial\end{array}$ \\
\hline & & त्क & & & & & & & & \\
\hline -kt- & piece & & t fokto & t fotko & $\begin{array}{l}\text { t } \mathrm{otk} \\
\mathrm{o}\end{array}$ & t fotko & $\begin{array}{l}\mathrm{t} \int \mathrm{otk} \\
\mathrm{o}\end{array}$ & t fotko & $\begin{array}{l}\text { t } 0 \text { otk } \\
\text { o }\end{array}$ & t fokto \\
\hline$-\mathrm{pt} \int-$ & $\begin{array}{l}\text { padloc } \\
\mathrm{k}\end{array}$ & क & kəpt $\int a$ & $\begin{array}{l}\text { kabd3 } \\
\text { a }\end{array}$ & $\begin{array}{l}\text { kabd } \\
\text { za }\end{array}$ & $\begin{array}{l}\text { kabd3 } \\
\text { a }\end{array}$ & $\begin{array}{l}\text { kabd } \\
\text { za }\end{array}$ & $\begin{array}{l}\text { kabd3 } \\
\text { a }\end{array}$ & $\begin{array}{l}\text { kabd } \\
\text { za }\end{array}$ & $\begin{array}{l}\text { kəbd3 } \\
\text { a }\end{array}$ \\
\hline -bd3 & $\begin{array}{l}\text { capctu } \\
\text { re }\end{array}$ & क & $\begin{array}{l}\text { kəbd3 } \\
\text { a }\end{array}$ & $\begin{array}{l}\text { kəbd3 } \\
\text { a }\end{array}$ & $\begin{array}{l}\text { kəbd } \\
\text { za }\end{array}$ & $\begin{array}{l}\text { kabd3 } \\
\text { a }\end{array}$ & $\begin{array}{l}\text { kəbd } \\
\text { za }\end{array}$ & $\begin{array}{l}\text { kəbd3 } \\
\text { a }\end{array}$ & $\begin{array}{l}\text { kəbd } \\
\text { za }\end{array}$ & $\begin{array}{l}\text { kəbd3 } \\
\text { a }\end{array}$ \\
\hline$-\mathrm{kd}-$ & can & स & səkdo & & & & & & & səkdo \\
\hline & & क्दो & & səgdo & $\begin{array}{l}\text { səgd } \\
\text { o }\end{array}$ & səgdo & $\begin{array}{l}\text { səkd } \\
\text { o }\end{array}$ & səgdo & $\begin{array}{l}\text { səgd } \\
\text { o }\end{array}$ & \\
\hline$-\mathrm{tt}^{\mathrm{h}_{-}}$ & stick & लट्ठी & lətt $\mathrm{th}^{\mathrm{h}}$ & lot ${ }^{\mathrm{h}} \mathrm{th}^{\mathrm{h}} \mathbf{I}$ & lot $t^{\mathrm{h}} \mathrm{h}^{\mathrm{I}}$ & lot ${ }^{\mathrm{h}} \mathrm{t}^{\mathrm{h}_{\mathrm{I}}}$ & lat $t^{h_{I}}$ & lətt $t^{h_{I}}$ & lətt ${ }^{h_{I}}$ & lətt ${ }^{h_{I}}$ \\
\hline$-\mathrm{tt}^{\mathrm{h}}-$ & slate & पत्थर & $\begin{array}{l}\text { pott }{ }^{\mathrm{h}} \mathrm{e} \\
\text { rə }\end{array}$ & $\begin{array}{l}\text { path } \mathrm{t}^{\mathrm{h}} \\
\text { ərə }\end{array}$ & $\begin{array}{l}\text { path }^{\text {hth }} \\
\text { ərə }\end{array}$ & $\begin{array}{l}\text { pat }^{\text {hth } \partial} \\
\text { rə }\end{array}$ & $\begin{array}{l}\text { patho }^{\text {ho }} \\
\text { rə }\end{array}$ & $\begin{array}{l}\text { patth }^{\text {hor }} \\
\partial\end{array}$ & $\begin{array}{l}\text { patthe } \\
\text { ro }\end{array}$ & $\begin{array}{l}\text { patthe } \\
\text { ro }\end{array}$ \\
\hline \multirow[t]{2}{*}{$-\mathrm{dd}^{\mathrm{f}}$} & $\begin{array}{l}\text { Boudd } \\
\text { ha }\end{array}$ & बौद्ध & $\begin{array}{l}\text { boudd } \\
\text { fi }\end{array}$ & $\begin{array}{l}\text { boudd } \\
\text { ə }\end{array}$ & $\begin{array}{l}\text { bəod } \\
\text { də }\end{array}$ & $\begin{array}{l}\text { bəodd } \\
\partial\end{array}$ & $\begin{array}{l}\text { bəod } \\
\text { də }\end{array}$ & $\begin{array}{l}\text { bəudd } \\
\text { ə }\end{array}$ & $\begin{array}{l}\text { bəod } \\
\text { də }\end{array}$ & $\begin{array}{l}\text { bəud } \\
\text { də }\end{array}$ \\
\hline & worm & गद्धे & $\begin{array}{l}\text { gedd }^{\mathrm{h}} \\
\mathrm{e}\end{array}$ & $\begin{array}{l}\text { gəd }^{\mathrm{f}} \mathrm{d} \\
\mathrm{fi}_{\mathrm{e}}\end{array}$ & $\begin{array}{l}\text { ged }^{\mathrm{h}} \\
\mathrm{d}^{\mathrm{f}} \mathrm{e}\end{array}$ & $\begin{array}{l}\operatorname{gad}^{\mathrm{f}} d^{\mathrm{f}} \\
\mathrm{e}^{-1}\end{array}$ & $\begin{array}{l}\operatorname{god}^{\mathrm{h}} \mathrm{d} \\
\text { he }\end{array}$ & $\begin{array}{l}\operatorname{gəd}^{\mathrm{h}} d^{\mathrm{f}} \\
\mathrm{e}\end{array}$ & $\begin{array}{l}\text { god } d^{\mathrm{h}} \mathrm{d} \\
\text { hie }\end{array}$ & $\begin{array}{l}\text { ged }^{\mathrm{h}} \mathrm{d} \\
\mathrm{f}_{\mathrm{e}}\end{array}$ \\
\hline
\end{tabular}

\section{References}

Adhikari S. (2014). History of Nepali Language. Kathmandu : Bhudipuran Prakashan.

Bhatta, D., \& Zhou J.X. (2019). Evolution and Features of Dotyali Consonants-A New Evidence for Historical Comparative Linguistics. Papers on Language and History. China: The Linguistic Institute. Sichuan Normal University (12): $1-22$.

Bhatta, D. (2020). Historical and Phonological Studies on Dotyali and its Dialects of 
Nepal. Doctoral dissertation. Sichuan Normal University.

Clements G.N. (1990). The role of sonority cycle in core of syllabification:Papers in Laboratory Phonology (J.Kingston and M.Becakam eds).Cambribridge and New York: Cambribridge University Press (1):283-333.

Maria G. (2001). Falling sonority onsets, loanwords, and Syllable Contact. The Main Session. Papers from the 37th Meeting of the Chicago Linguistic Society (Andronis, Mary, Christopher Ball, Heidi Elston and Sylvain Neuvel eds.) CLS 37. Chicago: Chicago Linguistic Society (1).

Maria G.. 2001. Exceptions to sonority distance generalizations. The Main Session. Papers from the 37th Meeting of the Chicago Linguistic Society ( Andronis, Mary, Christopher Ball, Heidi Elston and Sylvain Neuvel eds.) CLS38. Chicago: Chicago Linguistic Society (1).

Davis S. (1998). Syllable Contact in Optimality Theory. Journal of Korean Linguistics (23):181-211.

Murray, Robert, and Vennemann, Theo. (1983). Sound change and syllable structure in Germanic phonology.' Language (59) : 514 -528.

Chautaut RD.2013.The History and Spoken Language of That Time.Kathmandu: Lusha Press.

A Sociolinguistic Survey of Far-Western Development Region. (2012). Linguistic Survey of Nepal (LinSuN, Central Department of Lngistics: Tribhuwan University.

Clements G.N. (1990).The role of sonority cycle in core of syllabification: Papers in Laboratory Phonology (J.Kingston and M.Becakam eds).Cambribridge and New York: Cambridge University Press (1) :283-333

Sam, Z. (2017). Indo-European Reduplication: Synchrony, Diachrony and Theory: 264.

Kobayashi, M. (1970). Historical Phonology of Old Indo-Aryan Consonants.Japan:

Study of La nguages and Cultures of Asia and Africa Monograph, Series (42) 